after termination. Nevertheless, the patients who come for repeat terminations are mainly from social classes IIIb, IV, and V (table VI). Those started on a method of family planning other than intrauterine devices tend to revert to the sheath or no method at all by the time of their second unwanted conception (table VII). This emphasizes their failure to persist in effective contraceptive methods.

To prevent the further rise in the total numbers of terminations of pregnancy it is necessary to have a comprehensive system closely linking those carrying out the terminations and those providing the family planning services. Only in this way will contraception become effective in the prevention of recurrent abortion.

We would like to thank the staff of the gynaecological and obstetric departments at King's College Hospital and the staff of King's College Hospital Family Planning Brook Centre for their help; also the Department of Health and Social Security and the Marie Stopes Memorial Fund who have in part supported this work with grants

\section{References}

1 Gillespie, A., British fournal of Hospital Medicine, 1973, 9, 309.

2 Gordon, H., British fournal of Hospital Medicine, 1973, 9, 303.

${ }^{3}$ Office of Population Censuses and Surveys, Classification of Occupations. H.M.S.O., London, 1970.

${ }^{4}$ Lewis, S. C., Lal, S., Branch, B., and Beard, R. W., British Medical fournal, 1971, 4, 606 .

s Gilmour, M. G. D., Friend, J. R., and Beard, R. W., British Medical fournal, 1971, 1, 434.

Smith, R. J., and Newton, J., Fournal of Obstetrics and Gynaecology of the British Commonwealth, 1973, 80, 135.

Szabady, E., International Planned Parenthood Federation VIth Eurobean Regional Conference Report, p. 12. London, I.P.P.F., 1969.

${ }^{8}$ McEwan, J., Practitioner, 1970, 204, 427.

9 Buckle, A. E. R., and Anderson, M. M., British Medical fournal, 1972, 3,

381 .
${ }^{10}$ Collins, J. A., Allen, H. H., and Yuzpe, A. A., Canadian Medical Association fournal, 1972, 106, 1077 .

11 Stallworthy, J. A., Moolgaokir, A. S., and Walsh, J. J., Lancet, 1971, 4, 1245.

12 Sood, S. V., British Medical fournal, 1971, 4, 270.

13 Peel, Sir J., Unplanned Pregnancy: Report of Working Party. London, Royal College of Obstetrics and Gynaecology, 1972.

14 Morton Williams, J., and Hindell, K., Abortion and Contraception, p. 36. London, Political and Economic Planning, 1972.

15 Newton, J. R., Elias, J. A., and Newton, M. P., British Medical fournal, $1971,2,642$.

\title{
Screening in Medicine
}

\section{Screening for Abnormal Haemoglobins: A Pilot Study}

\author{
J. STUART, F. C. M. SCHWARTZ, A. J. LITTLE, D. N. RAINE
}

British Medical fournal, 1973, 4, 284-287

\section{Summary}

A pilot study has been made of the implications of screening for abnormal haemoglobins in immigrant schoolchildren. An abnormality was detected by capillary blood haemoglobin electrophoresis in $8.4 \%$ of 6,835 children and a haemoglobinopathy outpatient clinic had to be established to deal with the heavy work load which resulted. The clinic was also used to determine the value of investigating the remaining members of the family once an abnormality had been detected in one child.

Healthy siblings with normal haemoglobin electrophoretic patterns and normal iron and folate levels were studied to determine a normal range for haemoglobin in relation to age for adequately nourished immigrant children. The lower limit of the normal range was close to the mean value minus $1 \frac{1}{2}$ S.D.; by using this definition $10.3 \%$ of 280 children were subsequently found to be anaemic.

Popula tion screening of this type is desirable, but further pilot studies of patient education, genetic counselling, organizat ion of specimen collection, data processing, and follow-up health care facilities are required before screening is extended more widely in the United Kingdom.

Children's Hospital, Ladywood, Birmingham B16 8ET

J. STUART, M.D., F.R.C.P., Consultant Haemotologist

F. C. M. SCHWARTZ, M.R.C.P., D.C.H., Senior Registrar in Paediatrics A. J. LITTLE, M.SC., Biochemist

D. N. RAINE, PH.D., M.R.C.PATH., Consultant Chemical Pathologist

\section{Introduction}

The level of immigration to certain areas of the United Kingdom is resulting in changes in medical practice; at least $20 \%$ of new patients registered at this hospital are now of Asian or Negro descent. When an abnormai haemoglobin is detected by electrophoresis in a hospital patient it is logical to investigate also the siblings, parents, and other relatives. This requires one interview to collect the specimens and at least one follow-up interview to explain the results, to give genetic counselling and perhaps advice on diet, and to investigate unexplained anaemia and other abnormalities. The organizational effort and increase in work load within the hospital can be considerable.

This random contact with immigrants, occasioned by their need to attend hospital, can be supplemented by a screening programme extended to families who would not otherwise be referred for hospital investigation. This more extensive form of screening requires careful consideration of the social, medical, organizational, and ethical problems it would entail. The haemoglobinopathy screening programmes recently introduced in the United States have already illustrated some of the problems which arise ${ }^{1-5}$ and the value of routine screening of this type has been questioned. In the United Kingdom there are in addition very great difficulties of communication because of language differences.

A pilot study originating from this hospital was therefore introduced to define more clearly the value and implications of screening immigrant schoolchildren for abnormal haemoglobins, particularly in respect of the work load which would be generated. Screening of these children without simultaneous determination of, at least, the haemoglobin level is illogical. There is, however, a lack of information on the normal haemoglobin range in adequately nourished immigrant children, and this pilot study was therefore used to determine a lower level of normality in relation to age. 


\section{Materials and Methods}

Capillary blood specimens were collected from immigrant schoolchildren attending either school health clinics or a special City of Birmingham clinic for new immigrants. Parental permission was obtained in each case. Blood was collected into two heparinized capillary tubes from each child, as described by Raine et al., ${ }^{6}$ and the specimens were either delivered to the laboratory on the same day or posted overnight. The cells were packed in a microhaematocrit centrifuge and the red cell section of the tube was cut off and shaken in distilled water using a Beckman Spinco Micromixer to effect haemolysis. The specimens were then subjected to starch gel electrophoresis using tris-EDTA-boric acid buffer $\mathrm{pH} 8 \cdot 6^{7}$ and the two halves of the gel stained with naphthalene black and orthodianisidine respectively. Agar gel electrophoresis at $\mathrm{pH} 6 \cdot 2^{8}$ was subsequently used to differentiate $\mathrm{Hb} \mathrm{S}$ from $\mathrm{Hb} \mathrm{D}$ and $\mathrm{Hb} \mathrm{C}$ from $\mathrm{Hb} \mathrm{E}$.

A selection of children with abnormal electrophoretic patterns was made on the basis of the haemoglobinopathy detected, and a letter was then sent to the parents offering a similar test for all family members. The families were required to attend a morning clinic at the hospital, where venous blood was taken under non-fasting conditions and investigated for cyanmethaemoglobin, ${ }^{9}$ serum iron, ${ }^{10}$ whole-blood folate, ${ }^{11} \mathrm{HbA}_{2},{ }^{12}$ and fetal haemoglobin ${ }^{13}$ concentrations.

\section{Results}

Out of 6,835 schoolchildren, comprising mainly immigrants of African or West Indian (60\%) and Asian (40\%) origin, 574 $(8.4 \%)$ were shown to have abnormal haemoglobin electrophoretic patterns (table I). One appointment card and explanatory letter (in English) was subsequently sent to 154 families requesting attendance for further investigation; 110 families kept this appointment and on average 4.7 out of 6.2 members of each family attended the clinic. Venepuncture was not performed on very young children and blood was therefore collected from an average of $4 \cdot 2$ family members.

TABLE I-Results of Screening by Haemoglobin Electrophoresis in 6,835 Schoolchildren

\begin{tabular}{|c|c|c|c|c|c|c|c|c|c|c|}
\hline \multicolumn{8}{|c|}{$\begin{array}{l}\text { Haemoglobinopathy Detected } \\
\text { Heterozygotes: }\end{array}$} & \multicolumn{3}{|c|}{ No. of Patients } \\
\hline A/S . & .. & . & .. & .. & .. & .. & .. & .. & 306 & \\
\hline $\mathbf{A} / \mathbf{C} \quad \ldots$ & $\ldots$ & $\ldots$ & .. & $\ldots$ & .. & $\ldots$ & . & .. & 116 & \\
\hline $\mathrm{A}_{8}$ variant & .. & .. & .. & . & $\therefore$ & $\therefore$ & $\therefore$ & .. & 49 & \\
\hline$A / D$ & .. & . & .. & . & . & . & $\ldots$ & .. & 36 & \\
\hline A/ $\beta$-thal. & . & .. & .. & .. & $\cdots$ & $\cdots$ & . & .. & 26 & \\
\hline $\begin{array}{l}\mathrm{A} / \mathrm{E} \\
\mathrm{A} / \text { hereditar }\end{array}$ & & & & $\cdots$ & . & .. & .. & .. & 13 & \\
\hline \multicolumn{5}{|c|}{$\begin{array}{l}\text { A/hereditary persistence of } F \\
\text { Homozygotes or double heterozygotes: }\end{array}$} & .. & . & .. & .. & & \\
\hline $\mathrm{S} / \mathrm{A}_{2}$ varian & & . & .. & .. & .. & $\ldots$ & . & .. & 8 & \\
\hline$S / C$ & & $\therefore$ & $\therefore$ & . & $\therefore$ & $\therefore$ & $\therefore$ & .. & 5 & \\
\hline $\begin{array}{l}S S \text { or } S / \beta-t] \\
D D \text { or } D / \beta \text {. }\end{array}$ & & . & .. & . & .. & .. & $\cdots$ & .. & 4 & \\
\hline $\begin{array}{l}\text { DD or } D / \beta- \\
C C \text { or } C / \beta-1\end{array}$ & thal. & $\cdots$ & $\cdots$ & . & .. & $\cdots$ & . & .. & 1 & \\
\hline \multicolumn{3}{|c|}{$\begin{array}{l}\mathrm{CC} \text { or } \mathrm{C} / \beta \text {-thal. } \\
\text { Other unusual bands* }\end{array}$} & $\because$ & $\because$. & : & $\because$ & $\because$. & . & $\frac{1}{4}$ & \\
\hline & & & & & & otal & orm & ies & 574 & $(8.4 \%)$ \\
\hline
\end{tabular}

\section{NORMAL VALUES FOR IMMIGRANTS}

In order to determine the frequency of anaemia in immigrant children a normal range for haemoglobin was established for healthy siblings found to have normal haemoglobin electrophoretic patterns and also normal serum iron and whole-blood folate levels. This provided a lower limit of normality for age for adequately nourished children, though helminthic infestation was not excluded at this stage. All immigrant Birmingham schoolchildren are, however, routinely screened for intestinal helminths. ${ }^{14}$ The lower limits of normal for serum iron (50 $\mu \mathrm{mol} / 1$.) and for whole-blood folate (40 $\mu \mathrm{g} / 1$.) accepted for this study were taken from the normal range established for our departments.
The mean, mean minus $1 \frac{1}{2}$ S.D., and the range of haemoglobin values obtained for age are given in table II. For adults the lower limits of normal for haemoglobin were taken as $13.5 \mathrm{~g} / 100 \mathrm{ml}$ for males and $11.5 \mathrm{~g} / 100 \mathrm{ml}$ for females. ${ }^{9}$

\section{EFFECT OF HETEROZYGOUS STATE FOR ABNORMAL HAEMOGLOBIN}

The mean haemoglobin concentration in heterozygous children was slightly lower than in siblings with normal haemoglobin electrophoretic patterns but the differences were not significant in any of the three age groups studied (table II).

When all patients were studied irrespective of their iron and folate concentrations, but excluding homozygotes and double heterozygotes, there was a slightly higher incidence of anaemia in heterozygotes compared with normal children (table III). This was largely due to the inclusion of a number of families, particularly with $\beta$-thalassaemia trait but also with $\mathrm{Hb} \mathrm{C}$ trait, who showed anaemia in several family members. The incidence of subnormal iron and folate levels was no higher in the heterozygotes than in normals.

TABLE II-Haemoglobin Concentrations $(\mathrm{g} / 100 \mathrm{ml})$ in Children without Iron or Folate Deficiency

\begin{tabular}{|c|c|c|c|c|}
\hline & & 1-5 Years & $5-10$ Years & $10-15$ Years \\
\hline $\begin{array}{l}\text { Normal haemoglobin } \\
\text { electrophoresis: } \\
\text { Mean } \pm \text { S.D. } \\
\text { Mean } 1 \frac{1}{2} \text { S.D. } \\
\text { Range } \\
\text { (No. of children) } \\
\text { Heterozygous } \\
\text { haemoglobinopathy } \\
\text { Mean } \pm \text { S.D. } \\
\text { Range } \\
\text { (No. of children) }\end{array}$ & $\begin{array}{cc} & \\
\cdots & \cdots \\
\cdots & \cdots \\
\cdots & \cdots \\
y^{*}: & \\
\cdots & \cdots \\
\cdots & \cdots \\
\cdots & \cdots\end{array}$ & 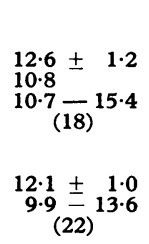 & $\begin{array}{l}13.0 \pm 0.9 \\
11.6 \pm 11.7-14.8 \\
\quad(29) \\
12.9 \pm 1.8 \\
10.4(69) \\
\quad 15.5\end{array}$ & 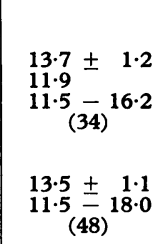 \\
\hline & $\mathbf{P}$ & $>0.1$ & $>0.5$ & $>0.5$ \\
\hline
\end{tabular}

${ }^{*} \mathrm{Hb}$ A/S 53 patients; $\mathrm{Hb}$ A/C 36 patients; $\mathrm{Hb}$ A/A variant 21 patients; Hb A/D 18 ${ }^{*} \mathrm{Hb} \mathrm{A} / \mathrm{S} 53$ patients; $\mathrm{Hb} \mathrm{A} / \mathrm{C} 36$ patients; $\mathrm{Hb} \mathrm{A} / \mathrm{A}_{2} \mathrm{v}$
patients; $\mathrm{Hb} \mathrm{A} / \beta$ thal. 7 patients; Hb A/E 4 patients.

TABLE III-Effect of Presence or Absence of Abnormal Haemoglobin (Heterozygous State) on Incidence of Subnormal Haemoglobin, Iron, and Folate Concentrations in Children and Adults. Results expressed as Percentage of Patients (Numbers of Patients studied are given in Parentheses)

\begin{tabular}{|c|c|c|c|c|c|}
\hline \multirow{2}{*}{\multicolumn{2}{|c|}{ Subnormal Value of: }} & \multicolumn{2}{|c|}{ Children } & \multicolumn{2}{|c|}{ Adults } \\
\hline & & $\begin{array}{c}\text { Abnormal } \\
\mathrm{Hb}\end{array}$ & $\begin{array}{c}\text { Normal } \\
\mathrm{Hb}\end{array}$ & $\underset{\mathrm{Hb}}{\text { Abnormal }}$ & $\underset{\mathrm{Hb}}{\text { Normal }}$ \\
\hline $\begin{array}{l}\text { Hb* } \\
\text { Serum iron } \\
\text { Whole-blood folate }\end{array}$ & $\begin{array}{l}\ldots \\
\cdots\end{array}$ & $\begin{array}{r}11.7(179) \\
9.5(168) \\
13.7(168)\end{array}$ & $\begin{array}{r}8.9(101) \\
19 \cdot 1(94) \\
15.6(109)\end{array}$ & $\begin{array}{ll}4 \cdot 1 & (74) \\
7 \cdot 0 & (71) \\
2 \cdot 7 & (73)\end{array}$ & $\begin{aligned} 5 \cdot 7 & (70) \\
12 \cdot 9 & (62) \\
4 \cdot 3 & (70)\end{aligned}$ \\
\hline
\end{tabular}

*For children the lower limit of normal for haemoglobin was defined as the mean of the control group minus $1 \frac{1}{2}$ S.D.

\section{EFFECTS OF AGE, SEX, AND RACE}

The overall incidence of subnormal haemoglobin, iron, and folate concentrations and the effects of age in children, sex in adults, and race are shown in table IV. Homozygotes and double heterozygotes are again excluded. In adult immigrants anaemia was found only in females and was almost certainly due to the higher incidence of iron deficiency. In children the incidence of anaemia declined with age and the highest incidence (at 1-5 years) again correlated with the peak incidence of subnormal iron levels. About one-third of the children in each age group were Asian, and these children appeared to be more prone to anaemia than Negro children; this difference was due to the inclusion of a few Asian families with several children heterozygous for $\beta$ thalassaemia and was no longer significant when heterozygotes were excluded. Subnormal folate concentrations were more common in Negro children at all ages. 
TABLE IV-Incidence of Subnormal Haemoglobin, Iron, and Folate Concentrations and the Effects of Age, Sex, and Race, irrespective of Heterozygous State for a Haemoglobinopathy (Numbers of Patients studied are given in Parentheses)

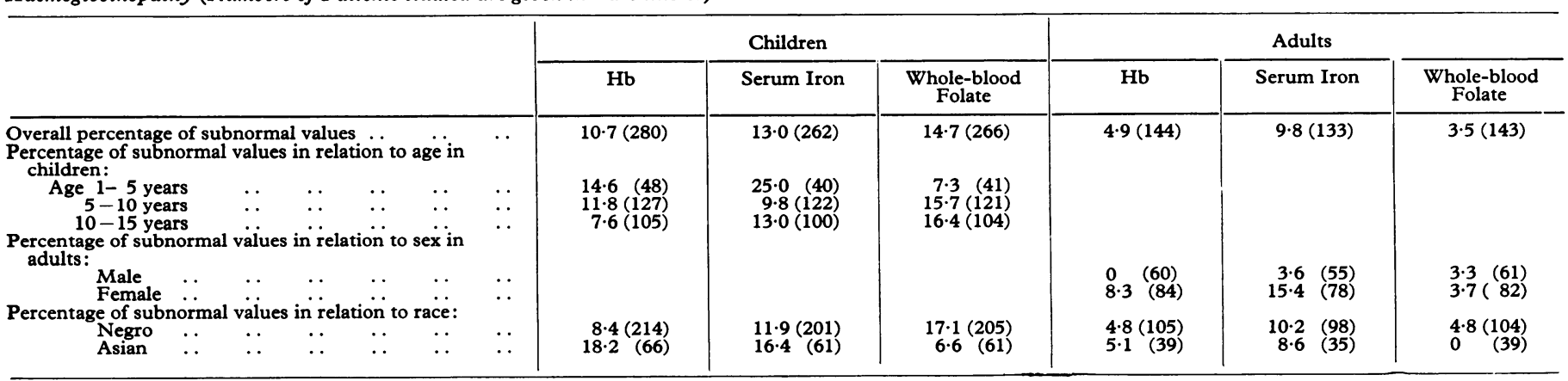

\section{FREQUENCY OF ABNORMALITY WITHIN FAMILY UNITS}

The incidence of anaemia for the study as a whole, including children and adults, was $7 \cdot 8 \%$. This increased to $28.1 \%$ in families studied as a unit after anaemia had been detected in one family member. Similarly, the overall incidence of $10.3 \%$ for either iron deficiency or folate deficiency or both increased to $19 \cdot 2 \%$ in families in whom one member was initially found to have subnormal values.

\section{Discussion}

Immigrant children of school age were selected for this pilot study since future community screening programmes with an educational and genetic counselling component are likely to be aimed at the school leaver. The overall incidence of an abnormality of haemoglobin electrophoretic patterns was $8.4 \%$, but for every school child screened there were $5 \cdot 2$ other family members. The additional abnormalities, including anaemia, detected in siblings and parents emphasize the value of studying the family as a unit. In practice only $71 \%$ of invited families actually came to the haemoglobinopathy clinic and one parent was usually absent in the families who did come. These attendance failures, the language difficulties, the amount of explanation required, and the need for a second clinic visit to explain the. results of the first add substantially to the work load.

One technician was able to haemolyse and complete the electrophoresis and clerical work for 50 specimens a day, a rate sufficient to keep up with the growth rate of the immigrant population in Birmingham. The bulk of the work load fell, however, on the school medical officers and the follow-up haemoglobinopathy clinic.

A haemoglobinopathy clinic is becoming an essential part of the routine paediatric service in hospitals serving a population with a high proportion of immigrants. This clinic provides the facilities to investigate the family as a unit and can be used to explain the significance of individual haemoglobinopathies and to give genetic counselling and other advice. Ideally translation facilities should be available.

The educational role of this clinic is of prime importance since the vast majority of patients detected by any screening programme are symptomless heterozygotes. In the present study only $0.3 \%$ of patients screened were homozygotes or double heterozygotes, and only these require hospital investigation and supervision. Apart from an occasional patient with mild anaemia almost all heterozygotes can be regarded as normal, though they may benefit from genetic counselling. This applies particularly to the $4.8 \%$ of patients found to be carriers for $\beta$-thalassaemia or sickle-cell trait.

While the availability of such a clinic relieves the load on certain busy general medical and surgical clinics it is desirable that most heterozygotes and their families should be cared for by their own physician. In order to assist new members of staff who are not experienced in the problems associated with haemoglobinopathies we have found it useful to issue, from the laboratories, an information sheet (see Appendix) which accompanies each haemoglobin electrophoresis report. These sheets state the implications of and recommended action for each of the individual haemoglobinopathies and provide a permanent form of reference in the hospital case folder. A duplicate sheet is issued which is forwarded to the family practitioner. Similarly, a list of drugs and agents with oxidant potential is issued for patients with glucose-6-phosphate dehydrogenase deficiency. In order to prevent rescreening of patients a selfadhesive diagnostic sticker is provided for the front cover of the notes and a medical card is also issued for the patient's personal use.

Purposeful screening by haemoglobin electrophoresis should be complemented by screening for anaemia and perhaps for other abnormalities such as glucose-6-phosphate dehydrogenase deficiency. While the recognition of anaemia is technically simple, the interpretation of borderline normal results in immigrant children is less so, since authors disagree on the lower limits of normal for haemoglobin for different ages. This reflects both technical differences and variation in the definition of a normal child. Some of the older series undoubtedly contained cases of iron deficiency which gave a falsely low value to the lower limit of normal ${ }^{15}$; this would apply even more to the establishment of normal levels in immigrant children owing to the uncertain and often inadequate dietary background.

A normal control series can either be taken from a group of children known to be receiving adequate iron ${ }^{15}$ or, as in this study, be defined by carrying out a solitary haemoglobin estimation while simultaneously checking that the blood levels of iron and folate are normal. This latter technique has been used in studies of South American populations ${ }^{16}$ and can usefully be combined with haemoglobinopathy screening programmes by studying siblings with normal electrophoretic patterns. Though study of a larger number of children at shorter age intervals is required to establish more precise levels for normal haemoglobin the lower limit of the range in each of the age groups found in the present study accords very closely with the mean values minus $1 \frac{1}{2}$ S.D., as found by Viteri et al. ${ }^{18}$

When this technique was used to define the lower limit for normal haemoglobin concentration some $10 \%$ of 280 immigrant children were found to be anaemic. The carrier state for most haemoglobinopathies did not increase the frequency of anaemia or of subnormal iron or folate concentrations except for a few families containing several anaemic children. These were usually carriers of $\beta$-thalassaemia or $\mathrm{Hb} \mathrm{C}$, both of which occasionally result in mild anaemia. ${ }^{17}{ }^{18}$ Folate concentrations were more often low in Negro children and their parents than in Asians. This contrasts with the high dietary intake of folic acid available to patients in Jamaica. ${ }^{10}$ Virtually every patient screened in this study had been resident in the United Kingdom for at least one year and the suboptimal folate levels in Negroes may represent a failure of dietary adjustment.

The wisdom of screening for sickle-cell disease and trait has been argued at length following the allocation of generous funds in the United States of America for screening centres and the legislation in certain states which has made screening of selected 
groups compulsory. The disadvantages of the American programme have been most cogently expressed by Whitten. ${ }^{5}$ Whitten's 11 points are an indictment of the way in which the programme has been introduced rather than of the value of screening itself. Careful consideration of the principles laid down by the McKeown Committee for any screening programme ${ }^{20}$ together with small pilot studies such as the present one are required to prevent the serious harm that can result from haemoglobinopathy screening programmes.

The present study has demonstrated the need for haemoglobinopathy clinics to deal with the work load generated by purposeful screening. It has also shown the need to study the family as a complete unit when an abnormality has been detected in one member. This has the additional advantage that data obtained from healthy siblings can be used to provide normal values for different ages in different racial groups. Future population screening programmes should be conducted with more emphasis on their educational and genetic counselling role. ${ }^{21}$ The prime requirement is for an educational service for the symptomless heterozygote with a benign condition. Further pilot studies are now required to determine how this, and genetic counselling, can best be achieved.

We are indebted to Dr. E. L. M. Millar, medical officer of health for Birmingham, Dr. N. M. Johnston and Dr. I. C. Aidney, senior and deputy senior school medical officers, and to all medical officers attending individual school clinics for their very active co-operation. Dr. C. R. Maddock assisted in the haemoglobinopathy clinic and a number of other colleagues helped with the laboratory investigations.

This work was supported by a grant from the United Birmingham Hospitals' Endowment Research Fund.

\section{References}

1 Culliton, B. J., Science, 1972, 178, 138.

2 Culliton, B. J., Science, 1972, 178, 283.

3 Ranney, H. M., Blood, 1972, 39, 433.

4 Fost, N., and Kaback, M. M., Pediatrics, 1973, 51, 742.

${ }^{4}$ Fost, N., and Kaback, M. M., Pediatrics, 1973, 51, 742. $288,318$.

6 Whitten, C. F., New England Fournal of Medicine, 1973,
6 Raine, D. N., et al., British Medical fournal, 1972, 3, 7.

7 Huehns, E. R., and Shooter, E. M., Fournal of Medical Genetics, 1965, 2, 48.

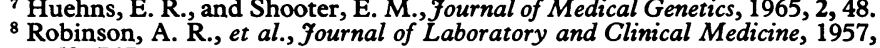
50,745 .

9 Dacie, J. V., and Lewis, S. M., Practical Haematology, p. 37. London, Churchill, 1968

10 Young, D. S., and Hicks, J. M., fournal of Clinical Pathology, 1965, 18, 98.

11 Hoffbrand, A. V., et al., Fournal of Clinical Pathology, 1966, 19, 17.

12 Bartlett, R. C., Clinical Chemistry, 1963, 9, 325

13 Singer, K., et al., Blood, 1951, 6, 413 .

14 Thompson, R. G., et al., British Medical fournal, 1972, 1, 591.

15 Moe, P. J., Acta Paediatrica Scandinavica, 1965, 54, 69.

16 Viteri, F. E., et al., British Fournal of Haematology, 1972, 23, 189

17 Weatherall, D. J., and Clegg, J. B., Thalassaemia Syndromes. Oxford, Blackwell, 1972.

18 Prindle, K., and McCurdy, P. R., Blood, 1970, 36, 14. . 19 Serjeant, G. R., et al., British Medical fournal, 1968, 3, 86.

19 Serjeant, G. R., et al., British Medical fournal, 1968, 3, 86. Oxford University Press, 1968.

21 World Health Organization, Technical Report Series, No. 509. Geneva, World Health Organization, 1972.

\section{Appendix}

INFORMATION SHEET FOR MEDICAL PRACTITIONERS

\section{Significance of Abnormal Haemoglobins}

The majority of patients from abroad who attend this hospital are screened for the presence of an abnormal haemoglobin. The following synopsis may be of help to you in interpreting results. A medical card stating, in abbreviated form, the result of the test is also sent to the patient.

Type of Recommended

Haemoglobin

Abbreviation

Likely Symptoms Action

Normal adult
(2) Heterozygous (Carrier) State with Minimal or no Symptoms

Heterozygous for:

$\mathrm{Hb} \mathrm{C}$

$\mathrm{Hb}$ D

$\mathrm{Hb}$ E

Thalassaemia

Heterozygous for

$\mathrm{A} / \mathrm{C}$

A/D

A/Thal

cell trait)

$\left\{\begin{array}{l}\text { Usually nil; may } \\ \text { be mild anaemia, } \\ \text { especially in } \\ \text { pregnancy } \\ \begin{array}{l}\text { Usually nil, } \\ \text { painful crisis } \\ \text { rare unless } \\ \text { severe hypoxia }\end{array}\end{array}\left\{\begin{array}{l}\text { Usually nil } \\ \text { Usually nil }\end{array}\right.\right.$

(3) Homozygous (or Double Heterozygous) State which may cause Symptoms Homozygous for:

$\begin{array}{ll}\text { Homozygous for: } & \text { C/C } \\ \text { Hb D } & \text { D/D } \\ \text { Hb E } & \text { E/E } \\ \text { Homozygous for } & \text { S/S* } \\ \text { Hb S (sickle- } & \\ \text { cell anaemia) } & \end{array}$

Mild haemolytic Anaemia may anaemia investigation Chronic haemoly- Early treatment of tic anaemia, infection, early painful crises, referral to recurrent hospital, avoid infections chilling, dehydration and

\begin{tabular}{|c|c|c|c|}
\hline \multirow[b]{2}{*}{$\begin{array}{l}\text { Homozygous } \\
\text { thalassaemia }\end{array}$} & \multirow[b]{2}{*}{ Thal/Thal } & \multirow{2}{*}{\multicolumn{2}{|c|}{ 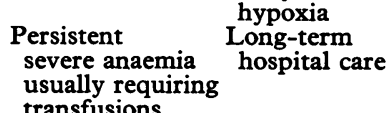 }} \\
\hline & & & \\
\hline $\begin{array}{l}\text { Heterozygous } \\
\text { for } 2 \text { abnorma- } \\
\text { lities }\end{array}$ & $\mathrm{S} / \mathrm{C}^{*}$ & $\begin{array}{l}\text { transtusions } \\
\text { As } S / S \text { but } \\
\text { anaemia less } \\
\text { severe }\end{array}$ & As $S / S$ \\
\hline & S/Thal* & As $S / S$ & As $S / S$ \\
\hline
\end{tabular}

${ }^{*}$ Notify hospital or dental practice anaesthetist before a general anaesthetic is given due to risk of sickle-cell crisis.

\section{Notes}

Homozygotes are born to parents who are both heterozygotes for the same condition; if heterozygotes marry one another then the risk of each child being a homozygote is $1 / 4$. Homozygotes for sickle-cell anaemia and thalassaemia are likely to be severely affected and this may deter a heterozygote for one of these conditions from marrying a heterozygote for either condition, or if they do marry, from having children.

When genetic advice is requested the diagnosis (which may have been reached by a simple screening test) should be reviewed and if necessary confirmed. Specialist genetic advice can be provided at this hospital if required. 